\title{
Manajemen Kebersihan Menstruasi pada Siswi SMA IT Nurul Ilmi di Kota Jambi
}

\author{
Ajeng Galuh Wuryandari ${ }^{1}$, Lia Artika Sari ${ }^{2}$, Netti Herawati ${ }^{3}$ \\ ${ }^{1-3}$ Jurusan Kebidanan Poltekkes Kemenkes Jambi \\ Email: ajenggw@poltekkesjambi.ac.id
}

Submitted : 28/12/2020

Accepted: 01/01/2021

Published: 11/01/2021

\begin{abstract}
Everyday, an estimated 300 million women and girls menstruate. The main problem for adolescents during menstruation is the lack of knowledge about menstrual hygiene management $(M H M)$. During menstruation, women should really be able to keep the reproductive organs extra clean, especially the vaginal part, because if they are not kept clean, it will cause excess microorganisms and can interfere with reproductive function. The purpose of this community service is to identify the knowledge and understanding of students about menstrual hygiene management. This activity was attended by as many as 150 students. The method used in this community service through several stages, including compiling an activity plan, coordinating and advocating with the school, the second stage, namely implementation by providing material on online menstrual hygiene management with ZOOM teleconferencing media, evaluating activities through Google Form. This community service was carried out at SMA IT Nurul Ilmi. The need for comprehensive reproductive health assistance and education related to menstrual hygiene management for young girls
\end{abstract}

Keywords: menstrual hygiene management, reproductive health, young women

\begin{abstract}
Abstrak
Setiap haridiperkirakan 300 juta wanita dan anak perempuan mengalami menstruasi. Pokok permasalahan pada remaja saat menstruasi adalah kurangnya pengetahuan tentang manajemen kebersihan menstruasi (MKM). Saat menstruasi seharusnya perempuan benar- benar dapat menjaga kebersihan organ reproduksi secara ekstra terutama bagian vagina, karena kalau tidak dijaga kebersihannya akan menimbulkan mikroorganisme yang berlebih dan dapat menganggu fungsi reproduksi. Tujuan pengabdian kepada masyarakat ini adalah untuk mengidentifikasi pengetahuan dan pemahaman siswi tentang manajemen kebersihan menstruasi. Kegiatan ini dihadiri oleh siswi sebanyak 150 orang dan 6 orang guru. Metode yang digunakan pada pengabdian kepada masyarakat ini melalui beberapa tahap antara lain menyusun rencana kegiatan, melakukan koordinasi dan advokasi ke pihak sekolah, tahap kedua yaitu pelaksanaan dengan memberikan materi tentang manajamen kebersihan mentruasi secara online dengan media telekonferensi zoom, evaluasi kegiatan melalui google form.Pengabdian kepada masyarakat ini dilaksanakan di SMA IT Nurul Ilmi Kota Jambi.Perlunya pendampingan dan pendidikan kesehatan reproduksi yang komprehensif terkait manajemen kebersihan menstruasi pada remaja putri
\end{abstract}

Kata kunci : kesehatan reproduksi, manajemen kebersihan menstruasi, remaja putri 


\section{PENDAHULUAN}

Masa remaja merupakan masa storm and stress, karena remaja mengalami banyak tantangan baik dari diri mereka sendiri (biopsychosocial factors) ataupun lingkungan (environmental factors) (Direktorat Jenderal Kesehatan Masyarakat., 2018) . Berdasarkan hasil Survei Kesehatan Berbasis Sekolah di Indonesia tahun 2015 (GSHS) dapat terlihat sebagian dari pelajar perempuan merasa kesepian dan khawatir berlebihan (Kusumawardani et al., 2015). Perubahan besar pada remaja putri di mulai dengan terjadinya Menarche (haid pertamayang merupakan awal dari fungsi menstruasi dan tanda telah terjadinya pubertas pada remaja putri). Remaja putri membutuhkan dukungan ketika mereka mulai menstruasi. Tanpa dukungan yang cukup, seorang remaja putri mungkin tidak tahu apakah itu 'Normal' atau bagaimana mengatasi permasalahan yang terkait dengan menstruasi.(World Health Organization, 2003)

\section{Studi global UNESCO (2014)}

Melaporkan terdapat hubungan erat antara buruknya fasilitas sanitasi di sekolah dan rendahnya angka melanjutkan sekolah siswa perempuan. Terbatasnya fasilitas sanitasi di sekolah ditambah minimnya pengetahuan juga mempengaruhi anak perempuan absen sekolah saat menstruasi. Sementara itu, di banyak budaya, menstruasi dianggap sebagai hal yang tabu untuk dibicarakan karena dianggap negatif, memalukan, kotor, atau penyakit. Pemahaman keliru yang diperburuk dengan keterbatasan akses informasi, menyebabkan banyak perempuan dan anak perempuan tidak memiliki pengetahuan terkait menstruasi dan cara mengatasi masalahnya. Fasilitas terkait manajemen kebersihan menstruasi (MKM) di negara-negara berpenghasilan rendah dan menengah juga masih kurang memadai. MKM yang buruk menyebabkan anak putus sekolah, tidak hadir di sekolah, dan masalah kesehatan seksual dan reproduksi yang dapat berdampak pada kesehatan dan sosioekonomi jangka panjang siswa perempuan.(Dewi, Pramana and Pramana, 2019)

Dengan banyaknya anak yang tidak sekolahpada saat pandemi ini perlunya pengetahuan tentang manajemen kebersihan menstruasi diintegrasikan ke dalam kurikulum pembelajaran jarak jauh dan online adalah cara penting untuk memastikan bahwa orang-orang, termasuk remaja putri memiliki pengetahuan yang mereka butuhkan pada periode pertama mereka dan dengan aman mengelola kesehatan menstruasi mereka selama pandemi ini. (Department of Child and Adolescent Health and Development (CAH), 2009; Ureport, 2020)

Setiap hari, diperkirakan 300 juta wanita dan anak perempuan mengalami menstruasi. Mampu mengatur menstruasi dengan aman, higienis, dengan percaya diri dan martabat sangat penting untuk kesehatan, pendidikan, hak asasi manusia, pembangunan ekonomi dan kesetaraan gender secara keseluruhan.Sebelum pandemi COVID-19 dimulai, lebih dari 500 juta wanita di seluruh dunia tidak memiliki apa yang mereka butuhkan untuk mengatur menstruasi mereka. Periode mestruasi tidak berhenti walau terjadi pandemi, hal Ini penting untuk memasukkan kesehatan dan kebersihan menstruasi kedalam rencana Intervensi tanggap darurat COVID-19 dan kebijakan lintas sektor, termasuk kesehatan dan pendidikan.(PLAN International, 2020)

Kegiatan pengabdian kepada masyarakat ini untuk memberikan pengetahuan dan sebagai strategi advokasi dalam upaya menumbuhkan kesadaran yang akhirnya tumbuh nya dukungan untuk manajamen kebersihan menstruasi. Kegiatan pengabadian kepada masyarkat dilaksanakan di SMA IT Nurul Ilmi Kota Jambi,menggunakan media telekonferensi dan metode diskusi. 
Kegiatan ini melibat mahasiswa prodi profesi kebidanan Poltekkes Kemenkes Jambi, sehingga memberikan pengalaman praktik di komunitas pada mahasiswa secara nyata dan peningkatan kepercayaan diri mahasiswa khususnya dalam praktik promosi kesehatan.

\section{TARGET DAN LUARAN}

\section{Target}

Target yang diharapkan pada pengabdian kepada masyarakat ini adalah

1) Pengetahuan dan pemahaman siswi tentang pentingnya Manajemen Kebersihan Menstruasi sehingga mampu menerapkan Manajemen Kebersihan Menstruasi di rumah dan lingkungan Sekolah

2) Siswi mampu menrefleksikan ulang materi yang di sosialisasi dan mengevaluasi pemahaman dan sikap mereka terhadap manajemen kebersihan menstruasi

\section{Luaran}

Luaran dari pengabdian kepada masyarakat ini adalah adanya peningkatan Pengetahuan siswi SMA IT Nurul Ilmi dan adanya penurunan stres pada siswa dalam menghadapi permasalahan terkait manajemen kebersihan menstruasi pada masa pandemi COVID-19

\section{METODE PELAKSANAAN}

Metode yang digunakan pada pelaksanaan kegiatan pengabdian kepada masyarakat ini melalui beberapa tahap antara lain:

\section{Tahap persiapan}

Persiapan dilakukan dengan menyusun rencana kegiatan dan melakukan koordinasi anggota tim, kemudian melakukan pendekatan dan advokasi ke pihak sekolah, dilanjutkan berkoordinasi untuk pelaksanaan kegiatan pengabdian kepada masyarakat

\section{Tahap Pelaksanaan}

Pelaksanaan dilakukan sesuai dengan jadwal yang telah disepakati antara pihak sekolah dengan tim pengabdian kepada masyarakat. Kegiatan dilakukan secara online dengan media telekonferensi ZOOM, Kegiatan di awali dengan memperkenalkan tim pengabmas, tujuan dari kegiatan dan tahapan kegiatan kepada siswi yang hadir, kemudian dilakukan penjelasan serta sosialisi mengenai Manajemen kebersihan Menstruasi, dilanjutkan dengan diskusi yang dibagi menjadi tiga kelompok kecil, dipandu oleh mahasiswa prodi profesi Kebidanan yang ikut menjadi tim pengabmas dan dosen tim pengabdian masyarkat selama kurang lebih 30 menit, diskusi juga di isi dengan games pertanyaan melalui media Quizizz, di akhiri dengan meminta siswa megisi evaluasi kegiatan melalui Google Form

\section{Tahap Evaluasi}

Evaluasi dilakukan dengan melakukan presensi kehadiran peserta kegiatan, meminta siswi untuk melakukan refleksi materi yang telah di diskusikan dan mengisi form evaluasi

\section{HASIL DAN PEMBAHASAN}

Manajemen Kebersihan Menstruasi merupakan aspek yang perlu diperhatikan perempuan karena pada saat menstruasi rahim sangat mudah terinfeksi. Tanpa pengelolaan kebersihan menstruasi, perempuan memiliki resiko yang semakin tinggi untuk terinfeksi terutama penyakit terkait alat reproduksi. (Poedyo Armanto, 2017)

Hasil dari pengabdian kepada masyrakat dengan memberikan pendidikan kesehatan tentang manajemen kebersihan menstruasi pada siswi SMA IT Nurul Ilmi Kota Jambi yang di hadiri oleh 150 siswi dan 6 orang guru, diharapkan adanya peningkatan pengetahuan remaja akan manajemen kebersihan menstruasi.

Kebiasaan menjaga kebersihan bagian reproduksi merupakan awal dari usaha menjaga kesehatan. Dimana saat menstruasi pembuluh darah dalam rahim terbuka 
sehingga mudah terkena infeksi. Personal hygiene pada saat menstruasi dapat dilakukan dengan cara mengganti pembalut setiap 2 jam sekali atau 3 sampai 4 kali dalam sehari, atau harus diganti sesering mungkin bila sudah penuh darah menstuasi. Pembalut dtidak boleh digunakan lebih dari 6 jam. (Diana 2009)

Menstruasi memiliki pengaruh terhadap psikologi perempuan baik pada saat pertama kali menstruasi maupun setiap periode menstruasi. Pada saat menstruasi perempuan cenderung menjadi lebih sensitif, mudah marah, serta mengalami perubahan nafsu makan akibat adanya perubahan kadar hormon estrogen dan progesteron di dalam tubuh. Dutta, Badloe(2016) menyatakan bahwa tingkat pengetahuan tentang menstruasi dan pengelolaan kebersihan saat menstruasi yang dimiliki anak saat pubertas berpengaruh signifikan terhadap kondisi emosionalnya. Pengetahuan dapat meningkatkan kepercayaan diri anak saat menghadapi menstruasi.

Hasil pengabdian kepada masyarakat ini didukung oleh penelitian Riska P (2017) tentang Upaya Menjaga Kebersihan saat menstruasi pada remaja putri menyatakan bahwa upaya menjaga kebersihan saat menstruasi pada remaja masih kurang $(56,4 \%)$ maka remaja putri perlu meningkatkan pengetahuan dalam menjaga kesehatan reproduksi saat menstruasi. (Riska Phonna 2017)

Sejalan dengan hasil penelitian Hastuti tentang studi kasus manajemen kebersihan menstruasi (MKM) siswa SD dan SMP di Indonesia menyimpulkan bahwa Pengetahuan, praktik dan keterampilan manajemen kebersihan menstruasi siswa masih rendah. Perlunya sosialisasi secara terus menerus untuk meningkatkan pemahaman berbagai pihak, khususnya siswa perempuan dan laki-laki terhadap isu menstruasi dan manajamen kebersihan menstruasi.
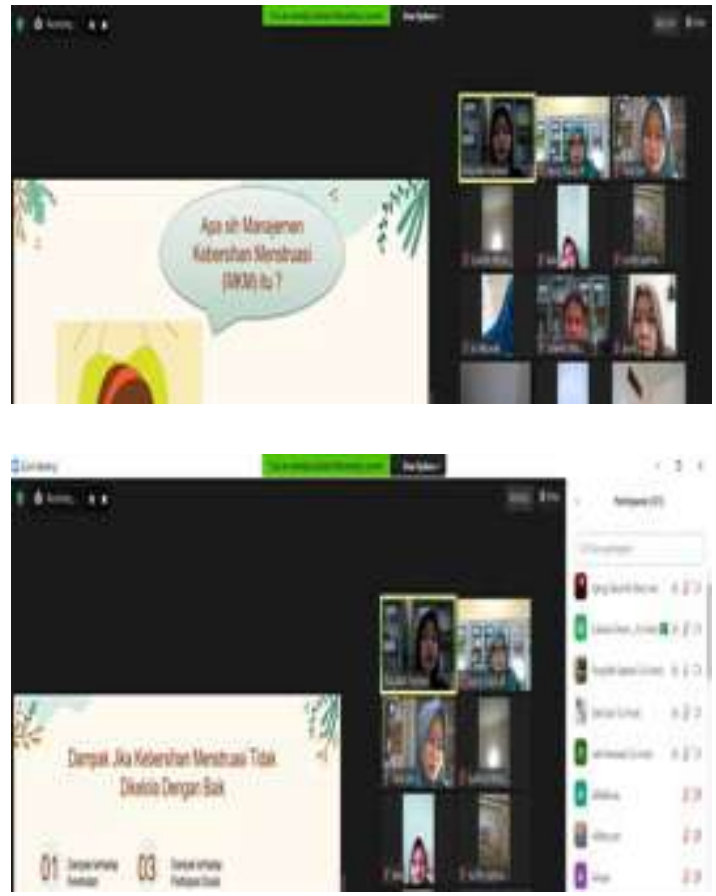

Gambar 1,2 Dokumentasi Kegiatan

\section{KESIMPULAN DAN SARAN}

\section{Simpulan}

Kegiatan pengabdian kepada masyarakat yang telah dilakukan berupa soasialiasi program manajemen kebersihan menstruasi menggunakan media telekonferensi ZOOM, materi yang di sampaikan bersumber dari pedoman dari UNICEF dan Kemenkes RI, dihadiri oleh 150 siswa dan 6 guru, dari hasil kegiatan diperoleh hasil adanya perubahan pengetahuan siswa akan pentingnya manajemen kebersihan menstruasi

\section{Saran}

Perlunya pendampingan dan pendidikan kesehatan reproduksi yang komprehensif baik kepada siswa perempuan maupun siswa laki-laki yang dapat dilakukan oleh guru sekolah. Perlunya advokasi lebih lanjut kepada pihak pimpinan sekolah untuk adanya perubahan sarana kebersihan sekolah yang terkait manajemen kebersihan menstruasi. 


\section{UCAPAN TERIMA KASIH}

Terima kasih kepada Kementrian Kesehatan RI yang telah memberikan dana pengabdian kepada masyarakat, Direktur Poltekkes Kemenkes Jambi dan Kepala Sekolah SMA IT Nurul Ilmi Kota Jambiyang telah memberikan izin dan memfasilitasi kegiatan pengabdian kepada masyarakat ini

\section{DAFTAR PUSTAKA}

Department of Child and Adolescent Health and Development (CAH) (2009) Strengthening The Health Sector Response To Adolescent Health And Development, World Health Organization. Switzerland. doi: 10.1016/b978-0-7295-3804-6.500635.

Dewi, R. K., Pramana, R. P. and Pramana, P. (2019) Studi Kasus Manajemen Kebersihan Menstruasi ( MKM ) Siswa SD dan SMP di Indonesia.

Direktorat Jenderal Kesehatan Masyarakat. (2018) Petunjuk Teknis Penyelenggaraan Posyandu Remaja. Edited by S. Khumaidah. Jakarta: Kementerian Kesehatan RI.

Kusumawardani, N. et al. (2015) Perilaku Berisiko Kesehatan pada Pelajar SMP dan SMA di Indonesia, Badan Litbangkes Kementrian Kesehatan RI, World Health Organization. Jakarta.

PLAN International (2020) Introduction: Periods Don ' $t$ Stop for Pandemics. United Kingdom.

Ureport (2020) Periods Don't Stop For Pandemics, WASH United Ureport World Association of Girl Guides And Girl Scouts. doi: 10.1192/pb.24.12.477.

World Health Organization (2003) 'Adolescent Friendly Health Services'. Switzerland: Department of Child and Adolescent Health and Development, WHO Geneva.

Riska Phonna, Farah Diba, Yuswardi, Maulina. Upaya menjaga Kebersihan saat menstruasi pada remaja putri. Idea Nursing Journal. Vol IX, No. 2 tahun 2017. ISSN 2087-2879

Dutta,D. Badloe C, Lee H.\&House S (2016) Supporting the rights of Girl and women Through menstrual Hygiene management (MHM) in the East Asia and Pacific Regio; Realities, progress and opportunities. Bangkok

Hastuti, Rika Kumala Dewi, Rezanti Putri Pramana. Studi Kasus Manajemen Kebersihan Menstruasi (MKM) siswa SD dan SMP di Indonesia. The SMERU Research Institute, 2019 